International Journal of Advanced Academic Research | Arts, Humanities and Education | ISSN: 2488-9849

Vol. 6, Issue 6 (June, 2020) |www.ijaar.org

Journal DOI: www.doi.org/10.46654/ij.24889849

Article DOI: www.doi.org/10.46654/ij.24889849.a6317

\title{
REFLECTIONS ON ECO-ACTIVISM IN THE NIGER DELTA IN CHIEMEKA GARRICKS' TOMORROW DIED YESTERDAY
}

\author{
Ijenebe Anwuri
}

\author{
And \\ Adebua Babatunde Olanrewaju (Ph.D) \\ Department of Languages and Literary Studies, \\ Babcock University, Ilisan Remo, Ogun State, Nigeria. \\ adebuab@babcock.edu.ng, +2348060685565
}

\begin{abstract}
Today, the Niger Delta, the cash-cow of the Nigerian economy, is notorious for two unsavory outcomes of oil activities in the region: environmental degradation and the subsequent militancy that resulted from the unchecked activities of oil corporations. Literature from the region subsequently reflects and refracts the ecological situations and instances of militancy in the Niger Delta. Although many studies have paid critical attention to the environmental concerns of the Niger Delta, very few have considered the less popular text of Chiemeka Garricks, which situates eco-activism in the Niger Delta with the restiveness of the youths in the area and the attendant socio-political issues it brings to the fore. Garricks presents the Niger Delta youth as a group that is disenfranchised economically and also sabotaged environmentally. This paper interrogates the tropes of eco-activism situated in the Garricks' Tomorrow Died Yesterday (2010). It traces the environmental concerns and how the novelist has positioned his characters as key stakeholders or voices in environmental advocacy. The study relies largely on Ecocriticism to underpin the economic emasculation of the Niger Delta people and the environmental degradation caused by oil activities. It also borrows from Lawrence Buell's second-wave eco-critical theoretical position to examine the environment and advocate for the environment and the victims of environmental degradation.
\end{abstract}

Keywords: Eco-activism, Eco-criticism, Environmental Degradation, Lawrence Buell, Chiemeka Garricks, Niger Delta. 


\section{Introduction}

The post-colonial Nigerian society has evolved into one bedeviled with a myriad of problems, ecological issues is a central discourse. The discovery of oil in Nigeria and the subsequent oil exploration, trade and activities have been a blessing to Nigeria, but more of a curse to the region that produces the wealth. Unarguably, the Niger Delta has been a victim of its own blessings. It has been vandalized, degraded environmentally, polluted and castrated due to oil exploration activities in the region. The environmental degradation recorded in the Niger Delta has brought about ecological issues of despoliation, climate change, global warming, and many more. These issues have subsequently led to agitations in the Niger Delta, positively and negatively. Negatively, it has led to aggressive actions from the youths of the Delta: militancy, kidnapping and insecurity trails and overshadows the activities of the oil companies.

The Niger Delta is a region with abundant natural resources (oil and gas), fertile land, rich forest and a water system with various fish species, which extends over a continuous tropical forest, characterized by a beautiful riverine environment. Unfortunately, this region, which accounts for a large percentage of Nigerian export earnings, particularly crude oil sales, is suffering from gross negligence on the part of the government and the oil corporations. Emmanuel Taiwo notes that "Since 1975, the devastation of the Niger Delta has become unbearable, with $2.5 \mathrm{~m}$ barrels of crude oil spilled or leaked into the delicate riverine environment resulting in the wholesale desecration of the fish stocks that most villagers depend on" (172).

Given this abundance of natural resources and the wealth the region provides the Nigerian government, oil-producing communities in the Niger Delta ought to be cared for. Poverty ought not to be synonymous with the region. Unemployment should not ravage the youths of the region. The government unfortunately neglects the people of the region in a brash way that shows that the government does not care for the environment. Cyril Obi submits that "in spite of the overwhelming contribution of the oil minority areas of the Niger Delta to Federal revenues, they have been excluded from direct access to oil revenues, except through federal and ethnic majority benevolence" (108).

This neglect and obvious marginalization of this region has threatened the socio-economic and political well-being, cultural practices and the environment of the region. The indigenes who are mainly farmers and fishermen have been forced to abandon their livelihoods due to oil spills, gas flares and continuous environmental degradation. Food becomes expensive for the people, yet the workers of the oil companies committing these atrocities flaunt their wealth - the proceeds of the rape of the region - in the face of the people. This direct consequence of pollution from crude oil and gas waste has led to the impoverishment of the Niger Delta population and left the people with respiratory diseases, deprivation and hopelessness. 
Since the environmental degradation of the Niger Delta is a direct product of man's action on nature, there is a need for man to engender a restorative process that will rejuvenate and reposition the environment to its former glorious nature. This process will require man to stop his inglorious acts against the environment. The need to restore the natural order and relationship between man and nature has led to varying degrees of outrage and protest from the Niger Delta people. Taiwo asserts that "the environmental devastation associated with the industry (petroleum) and the lack of distribution of oil wealth have been the source and/or key aggravating factors of numerous environmental movements and inter-ethnic conflicts in the region" (173). This, in general, has seen the youths turn to militancy, kidnapping and robbery in their fight against the multinational oil companies and the government.

The issues surrounding the Niger Delta are recorded by writers who reflect the Niger Delta, and Nigerian society in their writings. Writers like the late Ken Saro-Wiwa, Helon Habila, Kaine Agary (prose), Nnimo Bassey, Tanure Ojaide (poetry), Ahmed Yerima (drama) and many other Nigerian writers have drawn the attention of the world to the environmental devastation and inhumanity recorded daily in the Niger Delta in their literature. The works of these writers take an eco-activist stance highlight and illuminate the plight and predicament of the people of the region. These writers, through their craft, thereby shoulder the burden of writing and "righting" the wrongs of the Niger Delta. They become eco-activists who spearhead a change agenda albeit with resistance from the power blocs in the country. Their writings therefore show the connection between man and his environment and emphasize how human activities directly or indirectly affect the natural world. From this, it can be deduced that ecological criticism or environmental advocacy deal with radical unrest and the mobilization of all social forces to protect and preserve the natural environment. The aim is to raise awareness of contradictions within society, particularly with regard to the desecration of the ecosystem by state actors, individuals and organizations. In lieu of this, this paper founds its argument on Eco-criticism and Lawrence Buell's second wave eco-critical positions.

\section{Theoretical Framework}

Towards the end of the twentieth century there were clear indications that man has to do something to stop the destruction of the earth and avoid a global catastrophe; that there is an obvious need to refocus interest in the relationship between man and his physical environment and this has always been an area of interest for literary critics (Buell 2005:586). Scholars like Meeker (1972: 133) and Ruecker (1978: 71-86) are among the first set of critics to devote attention to ecological studies. Buell, Heise and Thornber (2011: 418) note that: 
Meeker's diagnosis of archetypal comic plots as reflecting strategies of adaptation in the interest of survival anticipates later interest in the pertinence of scientific models for environmental-literary inquiry. Influential studies by Leo Marx and Raymond Williams of pastoral traditions in American and British literatures in their ecohistorical contexts spotlighted literature as crucial to understanding the environmental transformations of urbanization and techno-modernity....

Eco-criticism deals with the relationship between literature and the environment, that is, how man's relationship with his physical environment is reflected in literature. Eco-criticism is without exception one of the ways in which humanists fight to save and preserve the earth against man's inhuman and polluting actions. Speek (n.d., 160) opines that Eco-critics are interested in how discursive conventions enable and constrain human contact with environment and place, the extent to which place informs representations, and the concrete ways by which means of representation informs man's sense of place. Early and notable critics of Eco-criticism include Lawrence Buell, Cheryll Glotfelty, William Howarth, Simon C. Estok, William Rueckert, Harold Fromm, Michael P. Branch, Suellen Campbell, and Glen A. Love.

Like any other study that receives ample attention, Ecocriticism 'has grown exponentially from its inception in the early 1990s as an organized initiative' (Buell et al. 2011: 418), which was The Association for the Study of Literature and Environment (ASLE). Today, eco-criticism has spread to other parts of the world, with each area in the world domesticating it to their relationship with the environment. Buell et al. (2011: 427) state:

Some postcolonial eco-critical monographs focus on individual regions, such as George Handley's New World Poetics (2007), which examines how writers from the Americas - the American poet Walt Whitman, the Chilean poet Pablo Neruda, and the Saint Lucian writer Derek Walcott - "discover and exploit the ideological flexibility of inherited human cultural patterns brought to bear in our human relationship to nature, specifically, the JudeoChristian myth of Adam in the Garden and its historic use to enable and justify environmental exploitation" [quoting Handley 2007, 4]. Eco-critical studies focusing on Caribbean literature have also analyzed creative depictions of the complicated relationships among ecological devastation, and (post)colonial trauma, myths of Eden and natural origins, and cultural creolization [citing De Loughrey, Gosson and Handley 2005, 303; Campbell and Somerville 2007, 173]. 
In Nigeria, critics like Tanure Ojaide, Enajite Ojaruega (2013), Chinoye Calista Ugwu (2014), Charles Cliff Feghabo (2014) and many more have adopted the theory to study the relationship between man and the Niger Delta environment, paying extensive attention to the environmental degradation recorded in the Niger Delta.

This study moves a little further from traditional Ecocriticsm to accommodate Lawrence Buell's second wave ecocritical positions. Buell, in The Future of Environmental Criticism, faults first wave Ecocriticism as tending to see nature and man as being opposite points, where one is almost the direct opposite of the other. He disagrees with this and holds that instead of the environment to be at loggerhead with man, "environmental criticism should be to help protect the natural environment from the depredations of human culture" (21). First wave Ecocriticism prioritizes the preservation of the environment, while Buell's second wave Ecocriticism takes a humanistic approach. It considers the economic effect of environmental issues on man too. It addresses both environmental issues and human issues. Buell surmises that:

The prioritisation of issues of environmental justice-the maldistribution of environmental benefits and hazards between white and nonwhite, rich and poor-is secondwave ecocriticism's most distinctive activist edge, just as preservationist ecocentrism was for the first wave. Among its crucial contributions have been its salutary broadening intensification of ecocritical concentration on nonwhite writers other than Native and a reconception of the stakes of the latter; its facilitation of the recent synergy between ecocriticism postcolonial studies described below; and a diversification ofthe ecocritical ranks, hitherto (and still) a markedly Caucasian group, to include more scholars of color (“Ecocriticism: Some Emerging Trend" 96).

Second wave Ecocriticism sees man and the environment as equal poles that are not opposite. It stresses peaceful relationship between man and his environment and advocates for both human and environmental justice. It addresses the inequalities between the rich and the poor, health hazards, minority and marginalization issues.

This paper therefore adopts Buell's tenets of second wave Ecocriticism to expose the plight of the Niger Delta people and advocate for a better life and environment for the people, as recorded in Chiemeka Garricks' Tomorrow Died Yesterday. 


\section{Plot Summary of Tomorrow Died Yesterday}

Chimeka Garrick's debut novel Tomorrow Died Yesterday tells the story of four friends Doughboy (Doye), Amaibi, Kaniye and Tubo who grew up together in the oil rich Asiama, situated in the Niger Delta region of Nigeria. The novel starts with the kidnapping of oil expatriate Brian Manning by Doughboy, the leader of the Asiama Freedom Army. Doughboy demands a ransom from the employers of Manning, Imperial Oil and asks that his childhood friend who is the communication officer of the company, Tubo, should secure the release of the man. His childhood friend and university lecturer Amaibi is asked to deliver the money because he is the one Doughboy trusts with the negotiation.

Unfortunately, Manning suffers a heart attack but Doughboy refuses to disclose this, yet he collects the ransom and returns Manning's dead body. Amaibi is jailed, so he recruits another childhood friend of theirs, Kaniye, a lawyer to represent him.

The novel stretches into the private lives of the four characters and tells their history of growing up as young boys in the Niger Delta, paying close attention to the 1997 incident that disrupted the lives of the boys. It exhumes the activities of the oil corporations and the extrajudicial killings and atrocities of the Nigerian military. It also shows the corruption that has gulped the leadership of the oil communities and the broken legal system of the country.

\section{The Rape of the Delta in Tomorrow Died Yesterday}

The discovery of oil in Asiama in 1970 attracts both local and international stakeholders. The discovery in itself is both a blessing and a curse. Asiama has joined the new league of oil producing communities that will host oil companies and be developed soon. These are the hopes of the people. However, time soon denies them of any of these blessings, instead it unleashes hell on them as their land is pilfered and raped. Soon, corruption finds its foot in Asiama and the people met with a poverty they had never envisioned.

Asiama is polluted beyond recognition. Gas flaring and oil spills soon become a daily occurrence in their lives. Even the little boys, Doye, Kaniye, Amaibi and Tubo recognize the hell in their land:

That is hellfire.

Tubo said it emphatically. He stood and pointed at the distance to the fire - raging unending, emitting black smoke, and sprouting from what looked like a vertical pipe. The fire was far away, somewhere up on the Asiama River, but it was visible from everywhere on Asiama Island. (80) 
The little boys do not know what this strange occurrence is, but they do know it is so hot that they cannot go near it. Animals are dying because of it and the island is losing itself to it. Amaibi recognizes it and tells his friends, "It is something called a gas flare." - a gift of the Imperial Oil company to the people of Asiama.

Asiama is raped to the extent that her people are rendered jobless. Fishermen are chased out of the river as the fishes turn up dead and farmers cannot farm because the farms are soaked in oil spills, which the oil company - Imperial Oil - does not clean. Doye narrates:

This year there was also something that happened up on Asiama River. We woke up one morning to see oil, thick and black, floating on top of the brown water of the river. The river became sluggish in its flow, as the oil gradually choked its life away. After school, I sat on the banks and watched dead fish, turned on their sides, slowly drift by. The river stank. Papa called it an oil spill. (97)

This is the environment the Niger Delta people are forced to adopt as their life and home.

It is not only the Niger Delta environment - Asiama - that is degraded. The lives of the Niger people are degraded too. Doye (Doughboy), Amaibi, Soboye and Mpaka are few of the characters who are recognizable victims of the Niger Delta struggle. Doye, a smart student, is caught in the web of man's inhumanity to his environment and his fellow man. His dream and future is shattered when his brother, Soboye, is killed in an oil bunkering fire. Oil bunkering wouldn't have been a job the Niger Delta youths would have resorted to if the government has provided for the community. The oil jobs are taken by the Yorubas and the Igbos while the Hausas take up the juicy political and security appointments, yet the producers of the oil are left with nothing. It seems the government even created the menace so that its officials could benefit from the illegal proceeds. Soboye tells brother, Doye: "Oil bunkering is not the same as stealing meat from somebody's pot. The government has a hand in it. I know this because Afonya says the navy turns aside as they sail away with oil. It is the biggest business in Nigeria. And except these people approve of you, you cannot enter the business" (92). The Niger Delta youth is therefore pawn in a larger chess game of politics of marginalization. Subsequently, Soboye like many other Niger Delta youths is killed in an oil fire. This does not stop the business as the cabals behind it only turn to another hungry Niger Delta youth to take his place.

Doye becomes a victim of the oil activities in his land after his future is truncated. He could not go to Lagos to write the scholarship exam because of the death of his brother. He is a peaceful young man until his father was killed along with thirty seven other Asiama men when the soldiers came to massacre the town for the death of one soldier. Doye sees the horror. He finds out his father has been brutally killed by soldiers for doing nothing. He sees how Gorimapa 
orders a full grown man to eat his faeces; how old men and women are flogged; and how the Amayanabo is asked to frog-jump. This destabilizes the average man. Even Kaniye, who doesn't like violence, becomes distraught after the 1997 incident. He affirms that violence is justified in the case of the Niger Delta. It is the only way the people can free themselves. Doye is a child of the Niger Delta. The 1997 event transformed him to Doughboy. Doughboy is a product of the Nigerian government and the marginalization of the people.

Doughboy and his Asiama Freedom Army become a collective representation of the marginalized youths of the Niger Delta. Doughboy sums up the situation of the future of the Niger Delta youth to Kaniye, "You still don't get it, Kaniye. Do you? There is no future for the children of the Niger Delta. Their tomorrow is already dead. It died yesterday" (236). The only way he believes he can fight for the freedom of his people is through the kidnapping of the oil workers. He knows he cannot win the war against the oil companies and the Nigerian government, but the only way to make them uncomfortable as the Niger Delta people are is through kidnapping:

Dise's first question was, 'Do you really think kidnapping of expatriates helps the people of the Niger Delta in any way?'

I shook my head and looked straight into her eyes, and the tripod-mounted camcorder behind her which was focused on my face. 'You've missed the point. It's not about helping the people of the Niger Delta. I think it's too late for that. It's about making it difficult for the bloodsuckers to loot our soil. It is war.....No. A revolutionary fights in the hope that he will change a system. I'm a realist. I know nothing I do will change the system. The system has made trillions of dollars from persistently brutalizing and sodomising my people. (247-8)

This justifies Buell's second wave Ecocritical positions. Environmental advocacy has gone beyond just showing the wrecks wrought on the environment. It has to show the wrecks wrought on the people's lives too. A whole region is being raped, sodomized and marginalized, yet the government and oil companies keep mute because of the wealth they accrue from the business. Eco-activism thereby falls on militant characters like Doughboy to advocate for both the environment and the marginalized people.

It is noteworthy that Doye is not the only victim of the marginalization. Amaibi becomes a victim too. Although he is a respected lecturer and environmental activist, this does not save him from the oppressive hands of the oil companies and the government. He is arrested for 
negotiating the safe release of the kidnapped expatriate, Brian Manning. He is even charged with planning the kidnapped. If Amaibi can be charged with planning the kidnap on the basis that he is a childhood friend of the kidnapper, Doughboy, then it is only logical that Tubo is picked up for the same reason, as he is also a childhood friend of Doughboy. However, Tubo is not a victim because he works for the oppressors. He is an agent of the oppressors while those who lend their voice to speak out against the evils of the oil companies and government are termed enemies and they are illegally prosecuted, as seen in the case of Amaibi. Sir James tells Kaniye as he is about to take up Amaibi's case that “... the government wants Amaibi out of the way. In this country the government is the Mafia. Everything has already been arranged. The trial will be merely to rubber stamp his predetermined conviction and the rest will be history". (69)

Even Kaniye knows that the judicial system of the country is fraught. Before Doye Koko loses his innocence after the soldiers killed thirty eight people and injured and beat one hundred and forty-two people for the death of one soldier, he asks Kaniye what the chances of their getting justice in the court of law, are. Kaniye:

...turned to him, 'What do you mean by justice? Do you mean justice from the courts? You think these soldiers will ever come to court? If Asiama people make enough noise, the best that can happen is that the military government will set up a panel of inquiry or some other bullshit committee who will find that the atrocities were committed by "unknown soldiers" acting outside command. Case closed. It's the end, we will only curse these soldiers, and hope that either God or the Devil is listening. That's the only justice we'll get. (290-1)

Kaniye knows the onions of the Nigerian judicial system very well. He has just won a landslide victory against Imperial Oil when he made this statement. He knows the victory is ensured because he had the oil company by its balls. However, this case is different. It is the government and the government will not take responsibility for their action. Also, with the case of Amaibi, he knows that the government and oil companies want to use Amaibi as a scapegoat. This is the reality of the Niger Delta lives.

Mpaka, Doye's father, is another victim of man's inhumanity to his environment. He is a fisherman, who loves drinking at the town square. His drunkenness status is not borne out of his love for alcohol, rather, it is his way of drowning his experiences. He is a survivor of the Biafra war. He knows the atrocities committed by soldiers during the Civil War. He is frustrated at the fact that Asiama is being raped continuously and her youths are denied opportunities to thrive. He loses his son, Soboye to oil activities and his farmland and home to the oil spills. His other 
son, Doye's future is denied him as he misses the scholarship exam in Lagos as a result of the pipeline explosion. The activities of the oil companies in the Niger Delta take away everything from him. He is slaughtered in an extrajudicious manner by soldier who ought to protect the citizens of the country.

\section{Conclusion}

Enco-criticism, today, has moved away from just stating the polar despoliation and degradation of the ecosystem by humankind. It has taken further steps to address the effects of human's activities on the environment and subsequently on humanity. In view of this, this paper has looked into the adverse effects of the activities of the oil companies and government on the people of Asiama in Chiemeka Garricks' Tomorrow Died Yesterday. Garricks uses his debut novel to advocate for the plight of the Niger Delta and her people. It exposes and decries the unprecedented despoliation and degradation of the ecosystem and people of the Niger Delta region of Nigeria. Doye Koko (Doughboy) loses himself, his identity as he tries to navigate life in the turbulent waves the oil activities of the Niger Delta have thrown him. Amaibi Akassa becomes an hunter that is hunted by the destructive powers that be. Mpaka loses everything he has used his life to build to the oil crises. The average lives of young Niger Delta men and women are ruined by the continuous presence of the oil companies in the region. 


\section{References}

Buell, L., U. K. Heise, and K. Thornber. 2011. Literature and Environment. Annual Review of Environmental Resources 36: 417-440. DOI: 10.1146/annurev-environ-111109-144855.

Buell, Lawrence. "Ecocriticism: Some Emerging Trends". Qui Parle 19.2 (2011): 87-115.

Buell, Lawrence. 2003. From Apocalypse to Way of Life: Environmental Crisis in the American Century. London: Routledge.

Buell, Lawrence. 2005. The Future of Environmental Criticism. Oxford: Blackwell.

Buell, Lawrence. The Future of Environmental Criticism: Environmental Crisis and Literary Imagination. Oxford: Blackwell Publishing, 2005.

DeMott, Nick. "A Brief History of Ecocriticism: Where Literature and the Environment Cross Paths". Medium. Web 20 Mar 2019.

Feghabo, Charles Cliff. 2014. Alienation and Ecoactivism in Selected Works on the Niger Delta Crisis.A PhD thesis submitted to the Department of English, University of Ibadan, Nigeria.

Garricks, C. 2010. Tomorrow Died Yesterday. Port Harcourt: Paperworth Books.

Glad, Derek. "Ecocriticism". Oxford Bibliographies. Web. 20 Mar 2019.

Handley, G. 2007. New World Poetics. Athens, GA: University of Georgia Press.

Leopold, Aldo. The Sand County Almanac: With Other Essays on Conservation from Round River. New York: Oxford University Press, 1966.

Meeker, J. 1972. The Comedy of Survival: Studies in Literary Ecology. New York: Scribner's.

Nwagbara, Uzoechi. "Poetics of Resistance: Ecocritical Reading of Ojaide's Delta Blues and Home Songs and Daydreams of Ants and Other Poems." African Study Monographs 31.1 (2010): 17-30.

Obi, Cyril. "Oil and Minority Question”.The National Questions in Nigeria: Comparative Perspectives. A. Momoh and S. Adejumobi (Eds). Hampshire:Ashgate Publishing Company, 2002.

Ruecker, W. 1978. "Literature and Ecology: An Experiment in Ecocriticism". Iowa Review 9(1): $71-86$.

Saro-Wiwa, Ken. Forest of Flowers. Port Harcourt: Saros International Publishers, 1986. 
International Journal of Advanced Academic Research | Arts, Humanities and Education | ISSN: 2488-9849 Vol. 6, Issue 6 (June, 2020) | www.ijaar.org

Journal DOI: www.doi.org/10.46654/ij.24889849

Article DOI: www.doi.org/10.46654/ij.24889849.a6317

Sheng, Anfeng. "Humanistic Concerns and the 'Second Wave' of Ecocriticism: An Interview with Professor Lawrence Buell’. Foreign Literature Studies 31.3 (2009): 1-10.

Speek, T. n.d. "Environment in Literature: Lawrence Buell's Ecocritocal Perspective". http://www.eki.ee/km/place/pdf/KP1_18speek.pdf (accessed on February 14, 2020)

Taiwo, Emmanuel. "The Poetics of Eco-activism in Ojaide's Tale of Harmattan." Ibadan Journal of English Studies 5 (2008).

Ugwu, Chinonye Calista. 2014. Ecological Degradation in Selected Niger Delta Novels. A PhD thesis submitted to the Department of English and Literary Studies, University of Nigeria, Nsukka. 